Article

\title{
A Multicriteria Decision-Making Approach of "Tree" Meaning in the New Urban Context
}

\author{
Luisa Sturiale ${ }^{1, *(\mathbb{C}}$, Alessandro Scuderi ${ }^{2}(-)$ and Giuseppe Timpanaro ${ }^{2}(\mathbb{C}$ \\ 1 Department of Civil Engineering and Architecture, University of Catania, 95127 Catania, Italy \\ 2 Department of Agriculture, Food and Environment, University of Catania, 95127 Catania, Italy; \\ alessandro.scuderi@unict.it (A.S.); giuseppe.timpanaro@unict.it (G.T.) \\ * Correspondence: luisa.sturiale@unict.it
}

Citation: Sturiale, L.; Scuderi, A.; Timpanaro, G. A Multicriteria Decision-Making Approach of "Tree" Meaning in the New Urban Context. Sustainability 2022, 14, 2902. https:// doi.org/10.3390/su14052902

Academic Editors: Marta Bottero,

Chiara D'Alpaos and

Francesca Abastante

Received: 29 December 2021

Accepted: 23 February 2022

Published: 2 March 2022

Publisher's Note: MDPI stays neutral with regard to jurisdictional claims in published maps and institutional affiliations.

Copyright: (C) 2022 by the authors. Licensee MDPI, Basel, Switzerland. This article is an open access article distributed under the terms and conditions of the Creative Commons Attribution (CC BY) license (https:// creativecommons.org/licenses/by/ $4.0 /)$.

\begin{abstract}
Future cities will need to plan and design urban green spaces and woodlands to meet diverse interests and needs, provide ecosystem services required by an evolving urban society and improve continuity between urban and rural spaces. This future planning approach calls for more sustainable patterns of urban growth, where forests and green spaces can help create more sustainable, resilient and inclusive cities, and address the challenges of a growing urban population. Green areas are of strategic significance because in addition to absorbing harmful pollutants, improving temperatures, and mitigating the impacts of climate change, they have a positive effect on people's health and well-being and help to create inclusive societies. The values considered are manifold and a multi-criteria assessment, including an evaluation of citizens' perceived needs, allowing policymakers to steer choices towards green-oriented urban planning tools, where green spaces and urban forests enable them to meet the challenges of future cities. The research presented here is part of this line of study in order to propose a tool to support stakeholders' decisions on urban green planning. The objectives of the study are to find out about the perception of urban green spaces and examine what kind of relationship should be established between the local authority and the population with regard to information and participation in the planning of green areas. The results highlight that citizens recognise the importance of ecosystem services and perceive green areas as strategic elements of urban quality of life, in agreement with some previous studies conducted in Italy and other countries.
\end{abstract}

Keywords: eco-system services; green-oriented urban planning; resilient cities; urban green spaces; urban forests; urban agriculture

\section{Introduction}

Cities occupy only $3 \%$ of the planet's surface, but consume $75 \%$ of natural resources. More than half of the world's population lives in cities, but by 2050 this percentage is expected to increase to almost $70 \%$ [1-4]. The development of these places depends on the fact that cities represent the core of a country's economy, with urban agglomerations accounting for about $80 \%$ of production activities and services. Urban activities, therefore, generate heat and pollution in the environment, alter biological cycles and are among the causes of the often irreversible loss of biodiversity $[2,5]$.

In Italy, according to the Legambiente report [6], out of 96 provincial capitals analysed in 2020, 35 exceeded the limits set by law for the daily concentration of particulate matter and 60 recorded an annual average of PM10 above the limits set by the WHO $\left(20 \mu \mathrm{g} / \mathrm{m}^{3}\right.$ per year) to protect the health of citizens. The report "The climate has already changed", drawn up by the CittàClima Observatory [7], shows that in the last 10 years, in Italy, there have been 946 extreme weather events in 507 municipalities. Floods, intense heat waves and tornadoes are just some of the extreme weather events that are increasingly frequent and intense in our urban centres. 
It is in cities that the most important challenge for building a sustainable future is played out, and it is from here that it is essential to act to protect our planet, in general, and to enhance the role played by urban greenery in cities, in particular, to rethink a new balance between nature and man in order to mitigate the negative impacts that intense urbanisation has caused so far $[8,9]$.

To this end, according to FAO, there is an urgent need to develop more sustainable urban growth models, in which urban greenery, urban forests and green spaces in general can contribute to creating more sustainable, resilient and inclusive cities and address the challenges of a growing urban population [10]. The importance of sustainable urban green management, highlighted by FAO, is also found in the 2030 Agenda for Sustainable Development, in particular Goal 11, Sustainable Cities and Communities, specifically dedicated to urban systems and whose ambitious goal is "Make cities and human settlements inclusive, safe, resilient and sustainable" [11].

The importance of urban greenery is linked to its ability to rebalance numerous environmental, energy, ecological and social parameters often altered by progressive urbanisation, with a consequent positive impact on the quality of life of urban communities. Numerous research have shown [9,12-19] that green areas can absorb harmful pollutants, reduce noise, improve temperatures, mitigate the impacts of climate change, provide a range of renewable products and energy, protect water sources and prevent soil erosion and flooding; moreover, they can have a positive effect on people's health and well-being and contribute to inclusive societies.

In this context, approaches and tools for assessing the value of ecosystem services provided by the green areas of our cities and innovative models for green-oriented urban planning are becoming increasingly interesting [20].

The objectives of the study were to find out about the perception of urban green spaces and to examine what kind of relationship should be established between the local authority and the population with regard to information and participation in the planning of green areas. The results show that respondents perceive green areas as strategic elements of urban quality of life and recognise the importance of ecosystem services, in agreement with some previous studies conducted in Italy and other countries.

The research carried out in the city of Catania (Italy) used an integrated assessment model that proved to be useful to analyse and evaluate citizens' perceptions of the importance of urban green and trees and the degree of interest in their participation in green-oriented urban planning. The results collected and the evaluation of the alternative scenarios proposed to the citizens, highlighted the validity of the proposed experimental model to translate the expectations of the involved citizens into possible directions in green-oriented, resilient and inclusive planning.

\section{Ecosystem Services Provided by Urban Green Areas}

Green areas and trees provide numerous functions that are essential to public health and the quality of the urban environment through their corresponding ecosystem services [21-28]. These ecosystem services are represented by the numerous benefits ranging from functional aspects, related to the nutrient and water cycle, to improving air quality, landscape characterisation, and even recreational and social aspects.

Ecosystem services are, according to the definition given by the Millennium Ecosystem Assessment [29], "the multiple benefits provided by ecosystems to humankind". The MEA describes four categories of ecosystem services which, in order of importance, are:

- Life support (related to the primary ecological function, thus linked to nutrient cycling, soil formation, etc.);

- $\quad$ Supply (relating to the production of food, materials, fuel or drinking water);

- $\quad$ Regulation (relating to the regulating function of climate and tides, pollination, water purification and pest control);

- Cultural values (including aesthetic, recreational, educational, spiritual). 
The CICES (Common International Classification of Ecosystem Services), i.e., the body that collects the work on "environmental accounting" (undertaken by the European Environment Agency (EEA), in concert with the System of Environmental-Economic Accounting (SEEA), currently led by the United Nations Statistical Division (UNSD)), in its 2018 report [30], has incorporated the functions related to life support, within those related to regulation.

The "urban green system" represents a real multifunctional resource for the city and its inhabitants and can take on the role of a tool for redevelopment, continuity and integration between the building recovery and the surrounding natural and agricultural environments, constituting and integrating corridors or ecological networks at a larger scale and thus contributing to decrease the vulnerability of the urban system through its multiple functions that become fundamental ecosystem services.

Below, we will briefly recall the different benefits that green areas can ensure in the urban context, based on the scheme proposed by the MEA [29].

\subsection{Provisioning Services}

Provisioning services are the functions linked to the supply of food, other resources and the maintenance of biodiversity. In urban areas, it is possible to enhance this function through urban agriculture, which has seen a development in recent years [6,31-33] and is capable of combining aesthetics, food, inclusive and social values of urban green spaces (edible landscaping) [34], and food forestry [35-37].

\subsection{Regulating Services}

Regulating services are the benefits associated with the regulation of ecosystem processes and, in particular, include:

- Improvement of air quality: a very important function both for the release of numerous chemical elements into the atmosphere and for the extraction of pollutants from the atmosphere. Increasing tree cover by $10 \%$ in cities could lower tropospheric ozone by approximately3\%, which is significant for this pollutant, particularly in places that need to reduce emissions to meet air quality standards [38]. Several studies carried out in Italy, Europe and the USA demonstrate the efficiency of evergreen plants in reducing air pollution [39-43].

- Climate improvement: trees and urban green belts have the ability to positively influence both climate and air quality in the surrounding area by limiting the heat island effect, increasing humidity and mitigating microclimatic excesses by providing shade. The cooling effect of large parks and green belts in terms of modifying urban heat islands has been measured and evaluated by many authors and it is generally acknowledged that there is a difference in air temperature of approximately 2-3 to $6{ }^{\circ} \mathrm{C}$ between the interior of large green areas (greater than $50 \mathrm{ha}$ ) and the surrounding built-up areas [44-46].

- Water, erosion and hydrogeological risk regulation: urban green areas contribute to the control of excess water runoff in case of heavy rainfall. Plant cover and the root system are key aspects of erosion control; plants enable soils to absorb a significant proportion of rainfall, which is then gradually released into both groundwater and surface water bodies. The roots of the plants hold the soil, while the aerial part intercepts the rain, preventing excessive compaction of the otherwise exposed soil.

- Habitats for biodiversity: green spaces are essential as they provide shelter, protection and living space for wild plants and animals (especially in their reproductive phase), whether residential or migratory species.

\subsection{Cultural Services}

Cultural services are the intangible ecosystem services provided to the population by the use of urban green areas and ecosystems. In particular, they can be represented by the 
enrichment of recreational and aesthetic experiences, health, social and inclusive, spiritual, cognitive development and reflection functions. Cultural values include:

- Inspiration for culture, arts, educational and spiritual values, sense of identity: ecosystems are a primary and irreplaceable source of inspiration for art, folklore, national symbols, architecture, advertising and provide the basis for formal and informal education in many societies.

- $\quad$ Aesthetic and landscape values: landscapes and natural areas represent increasingly sought-after aesthetics; this is reflected in the preference many people show for living in aesthetically pleasing environments and in the demarcation of "scenic routes" in supporting parks and selecting residential sites.

- Social and recreational values: urban green areas meet recreational and social needs, providing a fundamental service to the community, making an urban environment more liveable and human-scale. In addition, natural environments provide many opportunities for recreational, leisure and sports tourism activities: walking, hiking, camping, fishing, swimming, birdwatching and nature study.

- Health values: the space characterised by the green structure represents an element of dilution of psychological and humoral tensions for the people who use it, contributing to psychological wellbeing and mental balance as well as reducing the pathological effects deriving from the stress and pollution factors caused by the current urban system [47].

Ecosystems, therefore, provide humanity with a wide variety of essential services, but their real long-term value has not always been "accounted for" in society's economic forecasts and is still a subject of debate and discussion in the literature and in environmental policies.

For some time now, an attempt has been made to quantify, from an economic point of view, the value of these services at global level. Well known in the debate is the work of Costanza et al. [48] who estimated the value of the global flow of ecosystem services at USD 33,000 billion per year. This valuation (later criticized by Toman [49]) is an obvious underestimate of the actual Total Economic Value of ecosystem services, but we can attribute the merit of having opened the way to the problem of their economic valuation and, therefore, can be considered a first incomplete but important contribution, which has opened the strand of economic valuations of ecosystem services, on which there is still a lively debate in the literature, on the one hand, and among organizations in charge of climate change and biodiversity assessments, on the other. More recently, Elmqvist et al. [24], in a review that analysed the work produced on the subject, highlighted how the value of ecosystem services of green areas can be considered to be around USD 9700 per hectare per year, excluding the value of $\mathrm{CO}_{2}$ sequestration and positive effects on health, which are more difficult to determine.

The importance of urban green has been recognised at a European level for more than a decade through a series of documents and specific action plans, which have identified the strategic role of Green Infrastructures (GIs) (including urban green) in the fight against climate change. In particular, the term GIs was introduced in 2009 in the commission white paper "Adapting to Climate Change" [50]. GIs, according to the European Union (E.U.) definition, " ... are networks of natural and semi-natural areas planned at strategic level with other environmental elements, designed and managed in such a way as to provide a wide spectrum of ecosystem services. This includes green (or blue, in the case of aquatic ecosystems) and other physical elements in areas on land (including coastal areas) and marine areas. On the mainland, green infrastructures are present in a rural and urban context" [50].

It is possible to encounter some different ways of interpreting GIs, since in EU documents [50-52] the term "Green Infrastructures" is used in connection with landscape resources, especially for the aspect related to the conservation of biodiversity and ecosystem services in general. On the other hand, the European Environment Agency (EEA) and other European programmes use the term "green spaces," "green systems, "or "green structure" especially with reference to urban ecosystems [53]. In any case, beyond the choice 
of nomenclature, it is clear that the reference is always to the importance of the presence of trees and greenery (in the natural and/or urban environment) for the maintenance of important and essential ecosystem services for nature, man and the planet as a whole.

\section{Trees and Urban Green: A Strategic Necessity for Green and Resilient Urban Planning}

Green areas in cities represent a structuring element of cities also for a functional connection with rural peri-urban areas and should not be considered mere urban planning standards. The elements of GIs contemplated in cities must be included in the ecological network and treated with respect to their ecosystem services in the service of local settlement quality and wide area resilience.

The impacts that climate change may have on urban settlements have a wide range of variability, being a function of a complex set of contextual elements specific to each settlement, such as the altimetric location and wind regime, the size of the built footprint, the state of infrastructural facilities, the degree of availability of water and energy resources, the nature of economic activities, the income and education levels of the population, the extent of past criticalities with regard to hydrogeological risks, the provision of urban green spaces and services, mobility conditions, etc. Each urban settlement also expresses an adaptive capacity that can amplify or reduce impacts; the degree of awareness of citizens and the governance capacity of local administrations are also influential in this sense.

Urbanisation phenomena, which are diverse and complex in different countries, reflect on the ecology of ecosystems (natural and otherwise), both spatially (transformation of land use) and functionally (disappearance of ecological functions, resulting in increased vulnerability).

The process of progressive urbanisation has led to the continuous loss of soil, which in Italy between 2019 and 2020 was about 6000 ha per year of land consumed, i.e., 7\% of soil lost (compared to a European average of 4\%) [54]. In Italy, according to ISPRA 2021 estimates [54], the annual loss of ecosystem services resulting from the progressive consumption of urban soil could have a value between a minimum of 2.9 and a maximum of EUR 3.6 billion (in the period 2012-2020). The highest value is related to the service of regulating the hydrological regime, i.e., the surface runoff produced by soil consumption, which is responsible for the most evident negative effects in urban areas related to heavy and extraordinary rainfall. According to FAO “... Unfortunately, knowledge about urban soil biodiversity needed to guide sustainable planning and management of urbanized environments is woefully underdeveloped ..., ... our complete ignorance about urban soil biodiversity is a far greater threat than urbanization itself" [36].

The goal of bringing the city to less unbalanced and parasitic conditions can be achieved through targeted policy interventions and the adoption of good practices in order also to adapt to climate change. The attempt to rebalance the situation by at least mitigating free-riding, in relation to the different scales of reference, may be successful if it can be demonstrated whether and how the city can reduce the demand for matter and energy not only by intervening on consumption, reducing waste and optimising the performance of machines, but also by becoming a "producer" of energy and materials by optimising the opportunities within it. One of the key factors is the recovery of the solar energy systems present within it and in the areas connected to the rural space [23,39]. The fragmentation of green areas compromises the functioning of ecosystems, which need space to thrive and provide services. These systems must be a structural element and functionally subsidiary to the built system, subject to specific planning and design, taking into account that it is part of the natural capital, not exchangeable with other capitals and not monetisable. In fact, urban natural ecosystems, including through the inclusion of ecosystem service assessment as an integral part of city management, as already described, contribute to public health and increase the quality of life of citizens by improving their conditions of survival and the economic quality of the urban area by decreasing its vulnerability.

Consequently, it is becoming increasingly necessary to include natural components, trees and their ecosystem services in spatial transformation strategies, resulting in more 
effective communication about the identity value of places and the public value of resources, as well as the environmental impact and ecological, economic and social consequences. In this way, the benefits of a functioning ecosystem become immediately visible, and awareness of the usefulness of the services for both citizens and local decision-makers takes over; any threat to the ecosystem will have to be considered in terms of an environmental economic balance sheet, taking into account the benefits that would be lost and the socioenvironmental economic damage. Green-oriented planning that considers the functions of urban green ecosystems and their cycles (water, waste, energy, etc.) is of strategic importance as an ecosystem support for the sustainable development of the city and the well-being of its citizens.

Therefore, trees should be thought of as a public health infrastructure that can help the physical and mental wellbeing of citizens, precisely because of the benefits provided by trees and outlined in Figure 1.

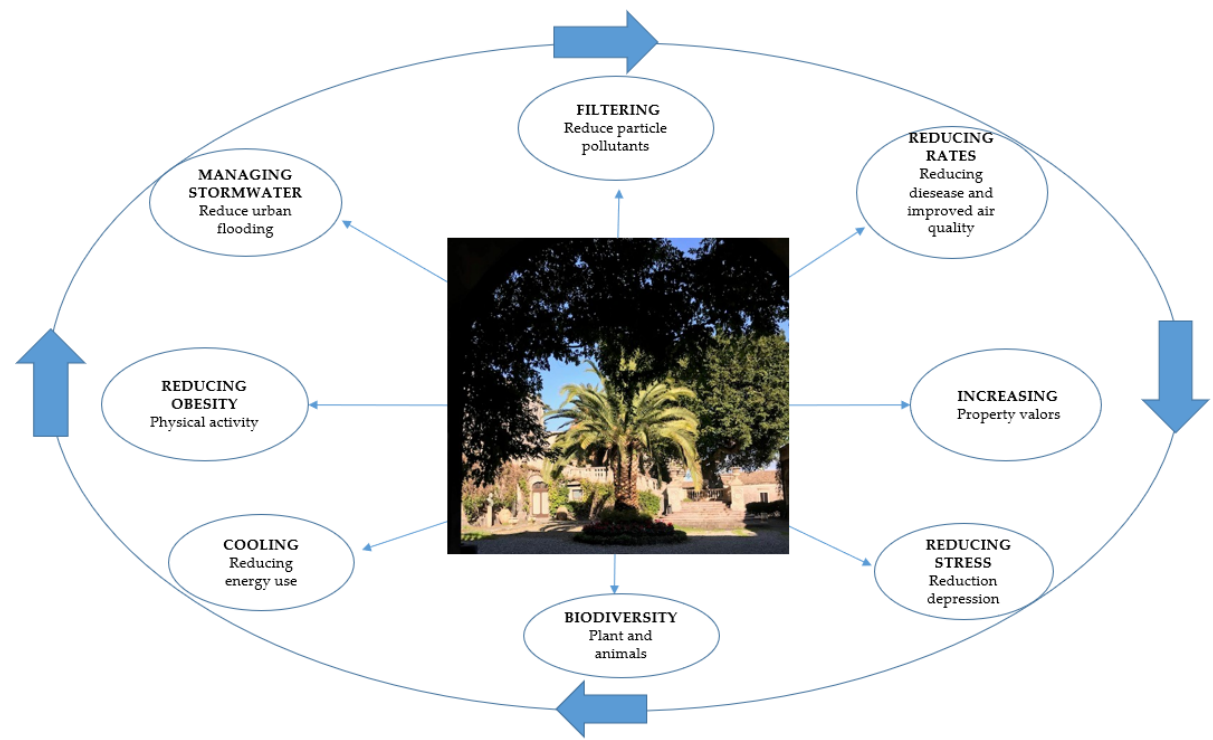

Figure 1. Benefits of urban trees (our elaboration with author's photo).

There is a vast literature on the relationship between citizens and urban green research that reports the evaluation of the benefits of urban green for residents [55-62]; in Italy too, surveys have been conducted on the level of citizens' perception of urban green $[63,64]$. In general, the results show that citizens value the recreational and aesthetic values of trees, but also attach great importance to other aspects (social, cultural, environmental), highlighting the growing attention of the population to the environmental quality of the city.

Given the ecosystem services provided by trees and their scientific and regulatory recognition, local governments should move towards green-oriented planning models, involving citizens and those interested in the design and care of urban green spaces in an increasingly important way. This new governance model is, among other things, suggested by several specific documents and studies [35,36], which have highlighted possible actions to foster the co-management of urban green spaces. In particular, we mention the actions considered most effective:

- Informing the population about the benefits of urban greenery and trees as an adaptation measure to climate change;

- Implement policies that encourage private citizens to plant trees;

- $\quad$ Link funding for trees and parks to health objectives;

- $\quad$ Facilitate collaboration between public health and environmental agencies;

- $\quad$ Educating the public about the public health benefits of planting trees as well as the economic impact of green areas.

Globally, there are many recent experiences undertaken by cities (both large and small) to increase the number of trees in urban settings, urban and home gardens, and green areas 
in general, to counteract the impacts of climate change in the first place. Maintaining the functional capacity of urban green spaces to mitigate the negative effects of climate change is far more beneficial than replacing these lost services with artificial technological solutions that are far more costly in terms of time and effort.

All over the world, urban green areas have been gaining popularity for at least a decade, both as a means of reducing climate change in urban areas and for their social and environmental benefits. It is not possible here to report on the many experiences of cities around the globe, either as completed or ongoing projects, but it is possible to mention some of the most interesting [9].

In the United States, several cities have planned the development of specific GIs (New York, Chicago, Washington D.C.) [65]. or have foreseen their presence in climate protection action plans (San Diego); Greenworks Philadelphia aims at turning Philadelphia into the "greenest city in America" with several projects to increase the presence of GIs in the city (Figure 2).

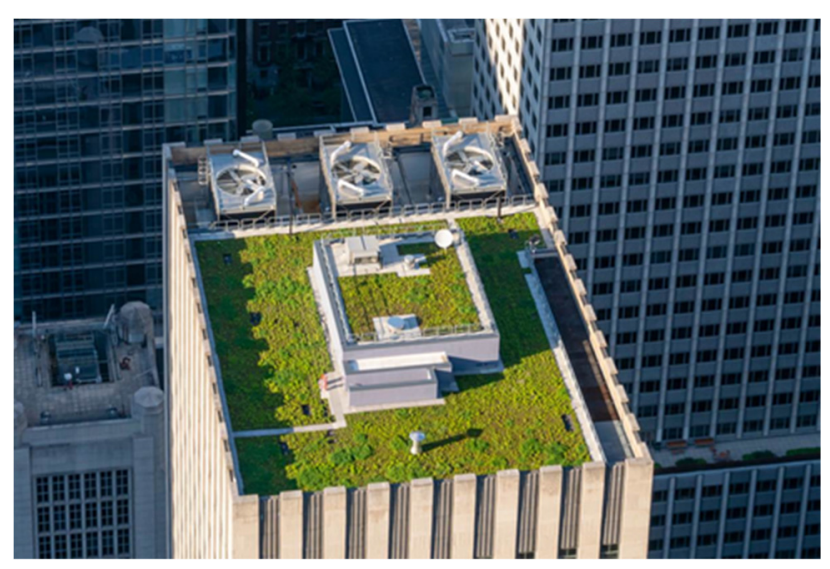

Figure 2. Green roofs in New York (www.greenme.it) (accessed on 20 September 2021).

From Northern Europe to the Mediterranean area, climate adaptation plans and experimental projects for the creation of sustainable eco-neighbourhoods have been adopted or are being developed, with the design of large areas of urban or suburban green space. The aim is always to introduce climate adaptation measures, on the one hand, and to regulate urban sprawl and the increasing senseless consumption of land, on the other.

Examples of the many initiatives include the UK's Green Belts (in UK urban planning), Barcelona's AnellaVerda, which comprises a network of 12 protected areas around the city connected by increasingly enhanced ecological corridors. Other projects and studies concerning the progressive inclusion of different forms of GI in the green planning of cities can be found from Europe to Asia: in Copenhagen [66], Berlin [67], Hong Kong [68], Beijing [69], and Nanjing's Pukou District [70].

In Australia, a plan to plant more than a billion trees has been financed in order to achieve the climate targets set at the last COP conferences, precisely because trees are the only truly effective way of reducing greenhouse gas pollution.

In New York, roofs will be transformed into green roofs, as decreed by a recent law making them compulsory, a measure included in the so-called Climate Mobilization Act, which will make the metropolis even more sustainable.

Paris has decided to plant 170,000 trees, continuing the green path already taken with the bicycle lanes. The reasons why the administration decided to design new green spaces are to make the French capital a resilient city to climate change and to offer a greener and more inclusive city to its citizens (as Amsterdam is already doing) (Figure 3). 


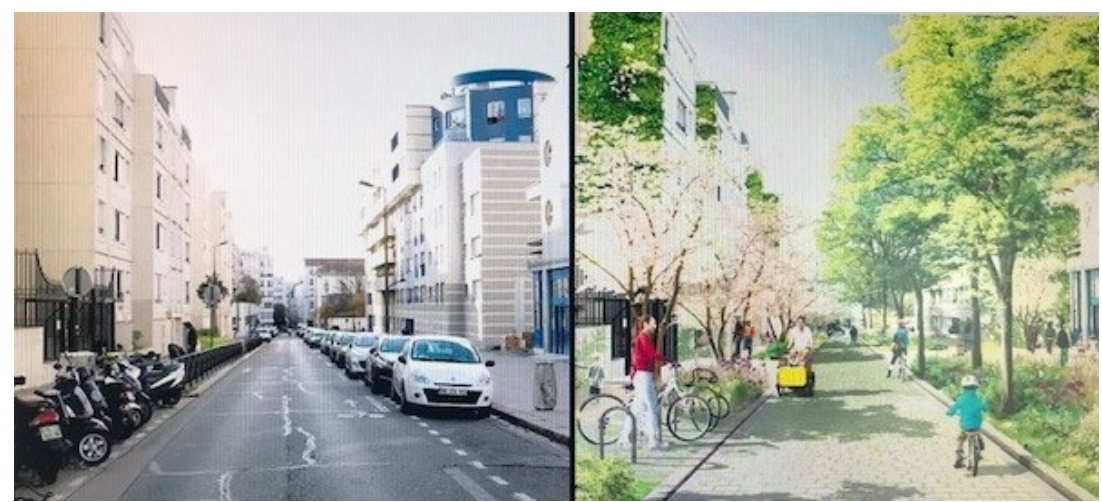

Figure 3. Paris streets: before and after urban greening (https://www.bikeitalia.it/2021/02/15 /parigi-piantera-170-mila-nuovi-alberi-come-togliendo-posti-auto/ (accessed on 15 February 2021)).

We could continue with similar initiatives in Barcelona (Figure 4), Seoul, Shanghai and others around the globe, even in countries known for other phenomena, such as Colombia. This country has planned "Green Corridors", with the aim of "two degrees less by planting trees". From Colombia, and in particular from Medellin, comes the success of a relatively simple and inexpensive solution to combat the rising heat in the cities. Based on a highly complex infrastructure which, to be installed and managed, does not require any major investment in technology or expertise: trees. Additionally, more generally, it uses the strategic deployment of public greenery in the urban area to mitigate the consequences of global warming.

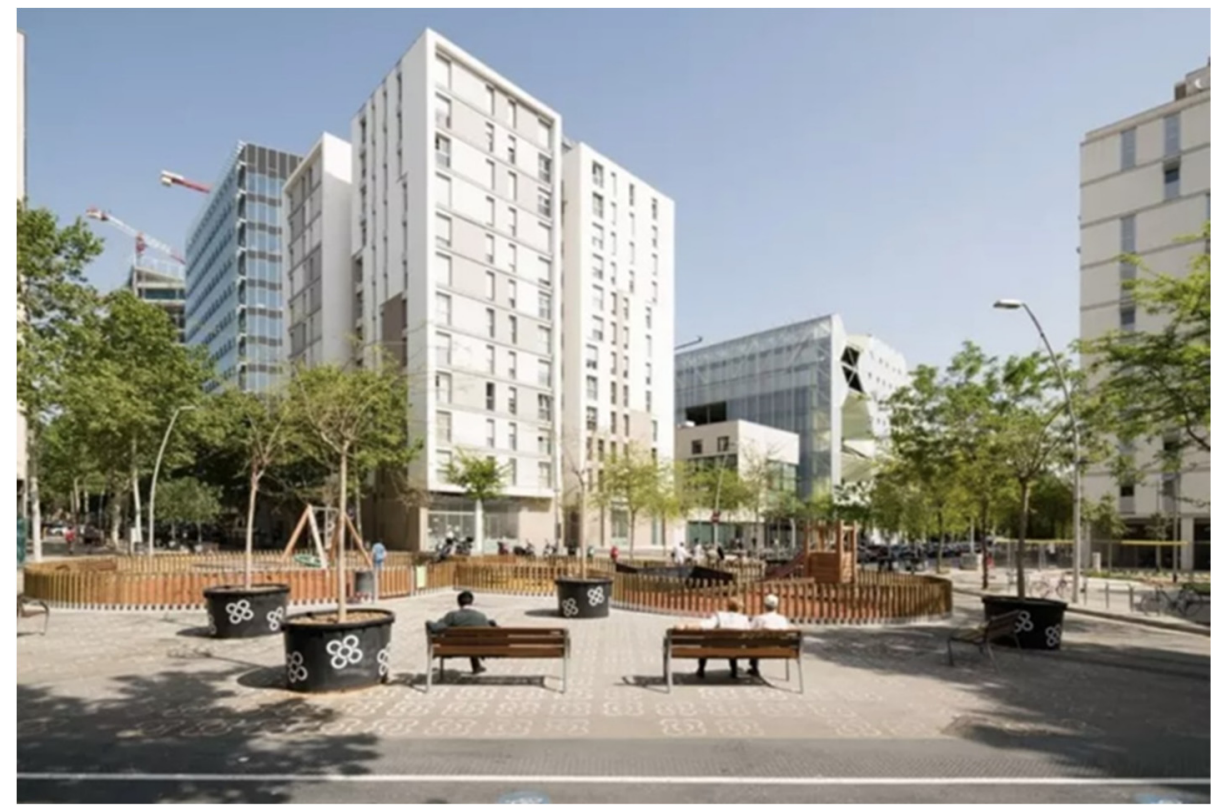

Figure 4. Green space in one of Barcelona's new green superblocks. (From concrete to urban green: a metamorphosis taking place in Paris, Shanghai and more cities-Domus (domusweb.it (accessed on 9 March 2021) (Photo HANDOUT/Ajuntament de Barcelona))).

The Green Corridors project solution has been defined by the International Union for Conservation of Nature (IUCN) as "actions to protect, manage and sustainably restore natural or modified ecosystems that address societal challenges in an effective and adaptive manner, while providing human well-being and biodiversity benefits".

In Italy, we mention the vertical forest in Milan (Figure 5); the Green Belt in Turin; the green ring in the municipality of Mirandola (Modena); the urban gardens in Catania [9]. 


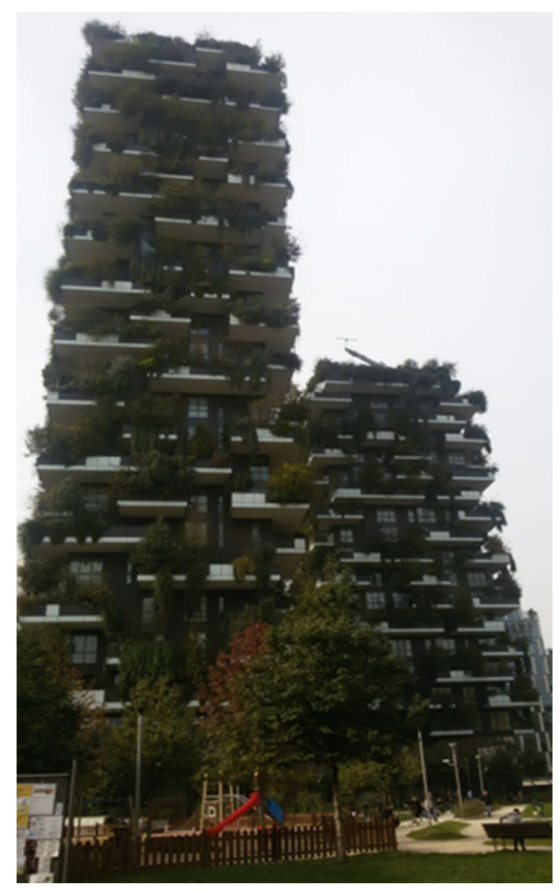

Figure 5. Vertical forest in Milan (author's photo).

Milan has set itself the objective of planting 30 million trees, following the same goals as other cities engaged in this "urban re-greening" action, making up for the gap that characterises Italian cities, which are a little behind in this "urban green revolution".

Additionally, in Lombardy, the first regional law on urban, peri-urban and metropolitan agriculture and on vertical farms has been approved. The law, which is also the first at national level on the subject, in addition to supporting urban agriculture, encourages the creation of urban woods, recognises green roofs in urban planning and allows the establishment of vertical farms (innovative vertical vegetable farms) in all urban areas.

It is not possible to report here on the innumerable green-oriented initiatives and experiences of cities, aimed at transforming urban environments into resilient and sustainable systems, from an environmental, social, energy and climate perspective.

In 2018, the FAO also launched a specific programme to make cities aware of the importance of the presence of trees in an urban context and enable initiatives aimed at increasing their presence. In particular, we refer to the "Tree Cities of the world" programme, in which Arbor Day Foundation also participates, which to date has involved 120 cities, scattered across all continents.

The green heritage of an urban area represents an important capital not only from an architectural and urban planning point of view but above all from an ecological-functional, social and economic point of view. The urban green system includes different forms, both natural and man-made spaces and systems, such as parks, green roofs, rain barrels, bioswales, street trees, permeable pavements, and community gardens. The natural capital of the city should always include those green areas that are more marginal but still important in defining urban biodiversity, such as residual strips of agricultural land, natural spaces, uncultivated land, avenues, gardens and parks of villas that were once typically rural, marginal areas, copses, wooded areas that are often limited and fragmented, road and railway buffer strips, banks of watercourses, uncultivated land, and so on. All these elements are part of an ecological network context, in which networks of natural and semi-natural areas are integrated, which it is important to plan at a strategic level with other environmental elements, and to design and manage in such a way as to provide a wide range of ecosystem services $[20,71]$. This pluriscalar organisation can be considered a truly complex system which, due to its ecological functions, is configured as a diffuse good of collective interest; in some ways, even a social service. Citizens' awareness of these 
functions and the importance of its value in an economic balance sheet, must trigger an appropriate responsibility that leads them to also participate directly in its management, according to a model of "multilevel governance" [20].

\section{Methodology}

The proposed methodology involves an integrated approach of participatory planning and multicriteria analysis. For multicriteria analysis, the NAIADE method (Novel Approach to Imprecise Assessment and Decision Environments) [72,73] was applied, together with the Parametric Evaluation of the opinions collected, using the Likert scale completed with the willingness to support the costs of green area maintenance. The study conducted in the city of Catania aims to find out about the perception of urban green spaces and to examine what kind of relationship should be established between the local authority and the population with regard to information and participation in the planning of green areas [74].

The objective is to develop a methodological framework with information and tools aimed at the acquisition and evaluation of information (qualitative and quantitative) [72,73] on possible alternative scenarios with respect to the proposed problem [75-77], and completed by the willingness to invest for the common good. The statements of the single subjects involved were collected through specific meetings with citizens, interested in the management of trees in the cities, under the different economic, social and environmental aspects.

The research was carried out in the post-COVID-19 period in June and July 2021. The collection of information was carried out through the administration of a questionnaire to a representative sample of 250 stakeholders of the population, with the help of focus groups, in order to probe the perception of environmental issues in the urban context and climate change and the real needs of the population in terms of demand for environmental quality and green infrastructure.

The research was carried out following the model described below (Figure 6):

- $\quad$ The identification of interested citizens (see Table 1);

- The definition of the questionnaire;

- The definition of the evaluation context;

- The use of focus groups as a social research methodology, aimed at acquiring information on citizens' opinions.

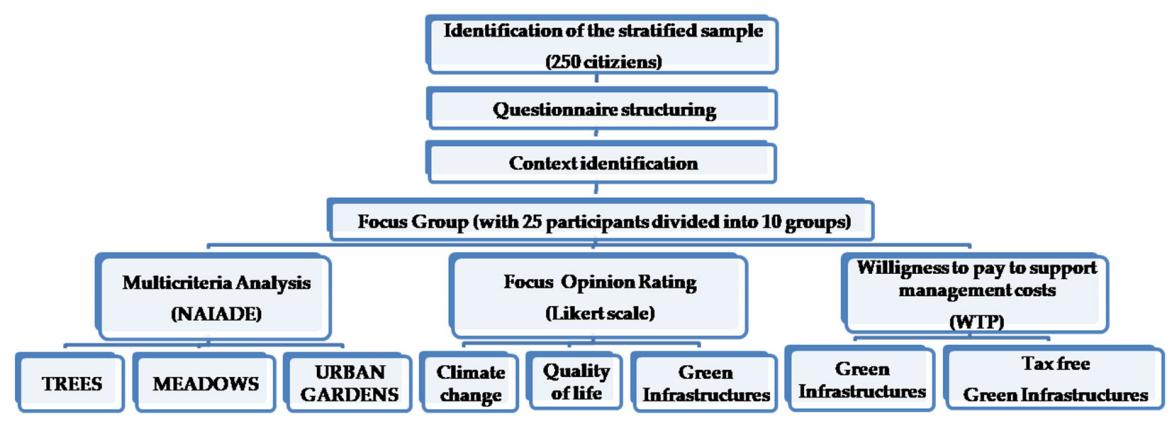

Figure 6. Research Structure (our elaboration).

The evaluation through focus groupswas preceded by the phase of planning of the meetings. During this phase, the following were established:

- $\quad$ The number of sessions and the time devoted to each of them (8, as an expression of the singlegroups considered, with a variable time from 4 to $8 \mathrm{~h}$ );

- The creation of an interview guide to lead the discussion (scientific and popular materials on the problems of urban green and the social and climatic effects that derive from it, photographic material on the different scenarios proposed);

- The selection of participants (stratified selection for non-homogeneous groups) (Table 1). 
Table 1. Stratification of subjects involved in the focus groups.

\begin{tabular}{ll}
\hline A1 & Citizens Associations \\
\hline A2 & Retirement Groups \\
\hline A3 & Cultural Associations \\
\hline A4 & Playrooms \\
\hline A5 & Trade Unions \\
\hline A6 & Institutions \\
\hline A7 & Scientific Groups \\
\hline A8 & Tertiary companies \\
\hline
\end{tabular}

A qualitative analysis approach was adopted, based on intentionally prepared inputs and specific rules, according to the stratification described in Figure 6. Focus groups can be considered social experiments, capable of producing collective opinions, revealing communication barriers, studying conflict behaviour, acquiring local information, creating acceptable options, synthesizing information, etc. Participants become key tools to support a "mutual learning process" on the issue under consideration. This technique of participatory confrontation makes it possible to reveal new dimensions of the issue under discussion, thus emphasizing the possibility for the focus group to bring out opinions about it rather than producing generalized results.

Step 1: For the multi-criteria analysis, the participants were asked to answer the following question:

What is the role of trees in different green infrastructures on citizen well-being and climate change? To this end, three alternative scenarios "TREES", "MEADOWS" and "URBAN GARDENS" were proposed.

In particular, the characteristics of the three scenarios are as follows:

- $\quad$ Scenario 1: TREES: presence of green structures with trees, without the possibility of an underlying trampling;

- Scenario2: MEADOWS: presence of lawns and shrubs, with possible direct use and trampling;

- Scenario3: URBAN GARDENS: presence of urban gardens, both productive and ornamental, with the presence of tree species.

In order to evaluate the three scenario hypotheses, evaluation criteria have been defined, which represent " . . a measurable aspect of judgment that can characterize a dimension of the different possibilities of choice considered".

Twenty evaluation criteria have been used, on the basis of the objectives envisaged, of the following types: Environmental, Social, Climatic, Economic, Landscape, Health Safety (Table 2).

Table 2. Objectives and evaluation criteria.

\begin{tabular}{ll}
\hline Objectives & Evaluation Criteria \\
\hline Environmental & Air Quality, Environmental Odours, Waste of water, Anthropisation \\
\hline Social & Usability, Productivity, Occupational engagement, Multifunctionality \\
\hline Climatic & Temperature reduction, Creation of shaded areas, Thermal excursion, Humidity \\
\hline Economic & Realization costs, Maintenance, Real estate value \\
\hline Landscape & Landscape Quality, Seasons, Biodiversity \\
\hline Security & Pollution, Plant Pathogens, Pesticid \\
\hline
\end{tabular}


The research, carried out in the city of Catania, focused in particular on the following 6 areas: Old Town, Borgo Sanzio, Picanello Ognina, Cibali Galermo, Nesima, Librino, excluding the peripheral areas of the municipality.

The interaction with the participants in the focus groups is the most important moment to carry out the activity of gathering information. To this end, an established structure for the meetings was followed, which initially provided for the presentation of the topic relating specifically to the action strategy for the management of urban green areas and the description of the trees present, with the use of supporting material (articles, results, photographs), prepared specifically to introduce the issue under consideration and stimulate discussion and interaction between the participants. At this step of the research, several ideas and opinions were acquired that represent the reactions of the participants involved in the questions.

Step 2: In the survey, respondents are asked to express their assessments of the effects of climate change in their city and the relationships between these and the presence of urban green. They were asked the question:

\section{- In your perception are the effects of climate change evident in Catania?}

The question serves as a basic discriminatory because it is assumed that an active participation in the management of urban green can come from those who perceive urban green as a provider of ecosystem services and a strategic element for adaptation to climate change. We then moved on to assess what the effects of climate changeare, perceived in their area of interest, applying a parametric scale (Likert scale 1-5).

The Likert scale was devised by the American psychometrician Rensis Likert in 1932 with the aim of developing a new instrument, simpler than others, for measuring opinions and attitudes [78]. It consists of a series of statements (items) semantically related to the attitudes one wishes to investigate; each item detects the same underlying concept, which is why it is a one-dimensional scale. Items are presented to respondents in the form of batteries. The respondent is asked to express his or her degree of agreement/disagreement with each statement by choosing from five response modes ranging from completely agree, agree, uncertain, disagree, to completely disagree (in the original version used by Likert they are defined as strongly agree, agree, uncertain, disagree, strongly disagree). Each response mode is given a score $(5,4,3,2,1)$, the sum (average) of the scores of the responses of each individual on the entire battery represents the individual's position on the concept under investigation. For this reason, the Likert scale is an additive scale.

For the evaluation of opinions on the specific topics according to the following rating scale (not at all (1), a little (2), average (3), enough (4), very much (5)) in the perception of interactions between urban green, quality of life and climate change.

The phenomena analysed in relation to climate change were summarized as hotter summers, increase in the number of hot days during the year, the presence of tropical nights, hot winters, winters with little rain, very intense rainfall over time called "bumps" of water.

We then moved on to assess, through the evaluation of citizens, what the main consequences are on the quality of life of citizens, defining as elements of assessment the following parameters: impact on the health of the most fragile people, increase in pests, poor liveability of public places, overheating of public places, increased consumption of electricity, power outage, city flooding, water supply difficulties.

Evaluating the perceptions that citizens have of climate change, we asked them to assess the benefits that green spaces involve regarding the climate in relation to air purification, temperature regulation, absorption of $\mathrm{CO}_{2}$, noise reduction, regulation of rainwater, enjoyment of the landscape use for recreation, walking, sports, etc., contact with nature, promotion of biodiversity, increase in property value, promotion of mental well-being.

Additionally, using photographic material on the different types of GIs present in the city of Catania, we asked respondents to indicate their preferences and which, among them, should be implemented by the municipality, in order to define what the priorities are of citizens in terms of urban green. 
Step 3: The research was completed with the third phase of the research, in order to acquire information on the potential willingness to bear the costs for the management of the common good (the public gardens).

Specifically, the following question was asked:

How much would you be willing to contribute financially to support green improvement in your area?

The interviewees of the focus groups have expressed their willingness to support the costs for public green, choosing between the following ranges of values: EUR 0 (no funds available), EUR 1-10, EUR 11-49, EUR 50-100, more than EUR 100. This amount is to be referred to as a one-off payment and referred to an area of specific interest, assuming the management of the green area by a private entity that would manage the green infrastructure.

The willingness to pay in the formula "green-tax" for the management of municipal green infrastructure was also noted, assuming the possibility of deducting the amounts paid for the management of green from the taxes to be paid to the Treasury of the Municipality of Catania which, in this case, have also been defined in the following ranges of intervention: EUR 0; EUR 1-10, EUR 11-49, EUR 50-100, more than EUR 100.

\section{Results}

The research has given information on the degree of perception of the importance of urban green infrastructure. The research assessed the degree of relationship between the presence of gardens and climate change and the first indications of willingness to bear the costs of maintaining and improving the urban green infrastructure.

The characteristics of the sample, is composed of $68 \%$ women and $32 \%$ men, divided into the following age groups: $46.2 \%$ 50-65 years, $23.1 \% 18-35$ years, $19.2 \% 35-50$ years and $11.5 \%$ over 65 years. As far as educational qualifications are concerned, $53.8 \%$ of the sample have a university degree, $26.9 \%$ a high school diploma and $19.2 \%$ have a secondary school diploma. Occupational positions are equally distributed among industry, commerce, public administration, schools and universities, craftsmen, healthcare and retired persons.

On the basis of the information collected, the impact matrix (Table 3) was drawn up, with reference to the three scenarios envisaged and the 21 evaluation criteria considered in the six evaluation macro-categories (environmental, social, climate, economic, landscape and safety) (described in Table 2).

The results show that the environmental criteria evaluate positively the "TREES" scenario in relation to air quality, the spread of odours, the limited anthropic impact and the limited waste of water compared to the other scenarios. With regard to this last aspect, the interviewees pay great attention to the management of water, evaluating the "MEADOWS" and "URBAN GARDENS" scenarios as very poor due to the high amount of water needed for management in relation to the characteristics of the climate in Sicily, with hot and dry summers.

As far as social aspects are concerned, the "MEADOWS" scenario appears to be the one most appreciated for its usability and multi-functionality, while positive evaluations have been registered for the urban gardens scenario in terms of productivity and employment. Moving on to analyse the climate-related aspects, it is evident that the "TREES" scenario, in relation to temperature reduction, creation of shaded areas and temperature excursions, has received the highest evaluation, with lower evaluations of the "MEADOWS" and "URBAN GARDENS" scenarios.

As far as the economic aspects are concerned, the "TREES" scenario has a better evaluation, both in relation to the limited costs of realization and to the greater conditioning of the value of the surrounding buildings, while it is poor in relation to the obtaining of productions for the community. As far as the landscape criteria are concerned, they have the same evaluation for both the "TREES" and "MEADOWS" scenarios for all the criteria considered, such as the quality of the landscape, the exaltation of the seasons and biodiversity. Finally, the last criterion analysed is related to the aspects of safety, also for 
these aspects it is noted the higher evaluation of the scenario "TREES" in relation to the limited pollution in its management as well as the limited control and use of pesticides and fertilizers.

Table 3. Evaluation of the results of the impact matrix of the different alternatives.

\begin{tabular}{|c|c|c|c|}
\hline Evaluation Criteria & $\begin{array}{l}\text { Scenario } \\
\text { "TREES" }\end{array}$ & $\begin{array}{c}\text { Scenario } \\
\text { "MEADOWS" }\end{array}$ & $\begin{array}{c}\text { Scenario } \\
\text { "URBAN } \\
\text { GARDENS" }\end{array}$ \\
\hline \multicolumn{4}{|l|}{ Environmental } \\
\hline Air Quality & Excellent & Very good & Good \\
\hline Environmental odours & Very good & Excellent & Good \\
\hline Anthropisation & Very Good & Good & Good \\
\hline Waste of water & Excellent & Poor & Poor \\
\hline \multicolumn{4}{|l|}{ Social } \\
\hline Usability & Good & Excellent & Poor \\
\hline Multifunctionality & Very Good & Excellent & Good \\
\hline Productivity & Poor & Good & Excellent \\
\hline $\begin{array}{c}\text { Occupational engagement } \\
\text { Climatic }\end{array}$ & Poor & Good & Very Good \\
\hline Temperature reduction & Excellent & Very Good & Good \\
\hline Creation of shaded areas & Excellent & Good & Poor \\
\hline Thermal excursion & Excellent & Very Good & Good \\
\hline Humidity & Very Good & Very Good & Good \\
\hline \multicolumn{4}{|l|}{ Economic } \\
\hline Costs of realization & Excellent & Good & Good \\
\hline Real estate value & Excellent & Excellent & Poor \\
\hline Maintenance & Poor & Good & Very Good \\
\hline \multicolumn{4}{|l|}{ Landscape } \\
\hline Landscape quality & Excellent & Excellent & Good \\
\hline Exaltation of seasons & Excellent & Excellent & Very Good \\
\hline Biodiversity & Very Good & Very Good & Excellent \\
\hline Security & & & \\
\hline Pollution & Very Good & Very Good & Good \\
\hline Presence of pathogens & Very Good & Very Good & Good \\
\hline Use of pesticides and fertilizers & Excellent & Very good & Poor \\
\hline
\end{tabular}

Source: our elaboration.

On the whole, the results of the multi-criteria analysis of the three hypotheses of urban green infrastructures (Figure 7) have shown that the "TREES" hypothesis, which provides for the presence of trees, even without a possible direct use, is the one that collects the greatest consensus at the level of almost all categories of respondents considered. The "MEADOWS" hypothesis is certainly the most preferred solution for some categories but, on the whole, not so much as to be preferred to the "TREES" hypothesis. The "URBAN GARDENS" hypothesis, while representing a very interesting multifunctional tool, is still less perceived and appreciated as a form of urban green in cities, able to coexist as an environmental, social and economic component, and even less as a measure of adaptation to climate change.

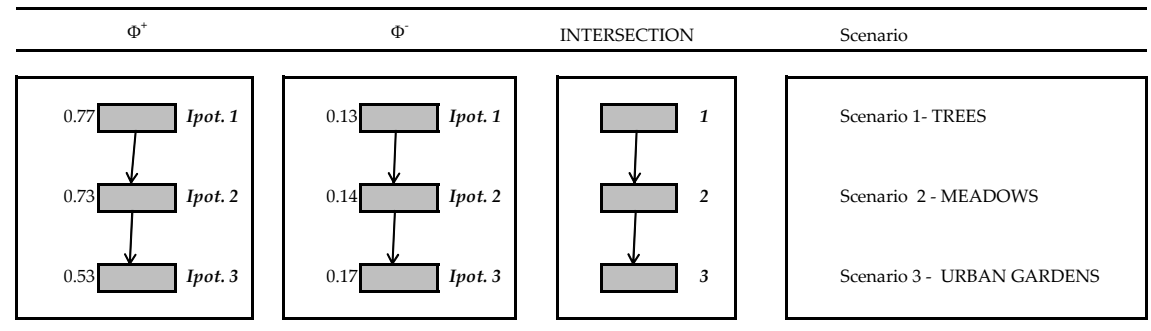

Source: our elaborations

Figure 7. Classification of alternative hypotheses of the multicriteria evaluation. 
Analysing the results by groups (Table 4), while confirming the results described above, it can be observed that, excluding some categories, the hypothesis "TREES" shows the greatest consensus. These results confirm that there is no univocity in the different hypotheses proposed, but that this depends on the expectations that each group has in the green areas indicated, as can be seen from the evaluation obtained by excluding some stakeholders from the evaluation, generating alliances between groups that lead to a greater sharing of the meadow scenario when excluding retirees, or maximum sharing of the trees scenario by excluding institutions from the evaluation. These divergences highlight how, in the different groups, there is no convergent position in the evaluation of individual scenarios with alliances and conflicts.

Table 4. Consensus levels and scenario priority definition.

\begin{tabular}{cccccccc}
\hline & \multicolumn{7}{c}{ Consensus Livels } \\
\hline \multirow{2}{*}{$\begin{array}{c}\text { Classification } \\
\text { of scenarios }\end{array}$} & 0.7749 & 0.7091 & 0.7817 & 0.7317 & 0.6328 & 0.6423 \\
\cline { 2 - 8 } & $\mathrm{A}$ & $\mathrm{A}$ & $\mathrm{A}$ & $\mathrm{B}$ & $\mathrm{A}$ & $\mathrm{A}$ \\
\cline { 2 - 8 } & $\mathrm{C}$ & $\mathrm{C}$ & $\mathrm{C}$ & $\mathrm{C}$ & $\mathrm{C}$ & $\mathrm{B}$ & $\mathrm{C}$ \\
\hline $\begin{array}{c}\text { Consensus based } \\
\text { on alliances }\end{array}$ & All groups & $\begin{array}{c}\text { All groups } \\
\text { exept A2 }\end{array}$ & $\begin{array}{c}\text { All groups } \\
\text { exept A8 }\end{array}$ & $\begin{array}{c}\text { All groups } \\
\text { exept A5-A6 }\end{array}$ & $\begin{array}{c}\text { All groups } \\
\text { exept A2-A4 }\end{array}$ & $\begin{array}{c}\text { All groups } \\
\text { exept A6-A7 }\end{array}$ \\
\hline
\end{tabular}

Source: our elaboration.

Regarding the second question of the survey, "In your opinion, are the effects of climate change evident in Catania?", the results show that the sample analysed affirms that the climate is changing, even if showing differentiated answers, as $50 \%$ of the sample declares that the effects are quite evident, $34.6 \%$ declares that they are moderately evident while only for $15.4 \%$ are they very evident.

Analysing which are the main consequences deriving from climatic changes, it is found that the phenomena correlated to climatic changes most perceived are hotter summers, very intense precipitations (defined as "bombs" of water).

For the assessment of the main consequences on their quality of life, the most frequent responses are related to the poor liveability of public places, increased consumption of electricity, and flooding of the city, while the perception is limited for other parameters considered, such as power failure, impact on the health of the most vulnerable people, increase pests, increased energy costs.

The benefits that urban green spaces bring to the quality of life of citizens are closely related to the use of the landscape, the use for recreation, walking and air purification, while the perception of ecosystem services produced by green areas and trees in the city is still poor with regard to temperature regulation, $\mathrm{CO}_{2}$ absorption, noise reduction, regulation of rainwater, positive effects on biodiversity, increase in real estate value, and promotion of mental well-being.

Going into the specifics of the individual types of GIs present in the city of Catania, the interviewees expressed a clear preference for the existing trees and parks, proposing their better maintenance, while taking a marginal position green roofs, vertical green, urban gardens and peri-urban forests. With regard to the information gathered on the willingness of the respondents to contribute to the work of landscaping the green areas of their neighbourhoods, an almost equal distribution of the sample identified was evident. In fact, $52.2 \%$ gave a positive answer, while $47.8 \%$ gave a negative answer.

The question that allowed to express the willingness of the respondents to support the costs for the improvement of urban green areas of their neighbourhood, with the hypothesis of a "one-off" payment, has collected the following responses, based on the economic ranges assumed (Figure 8): 


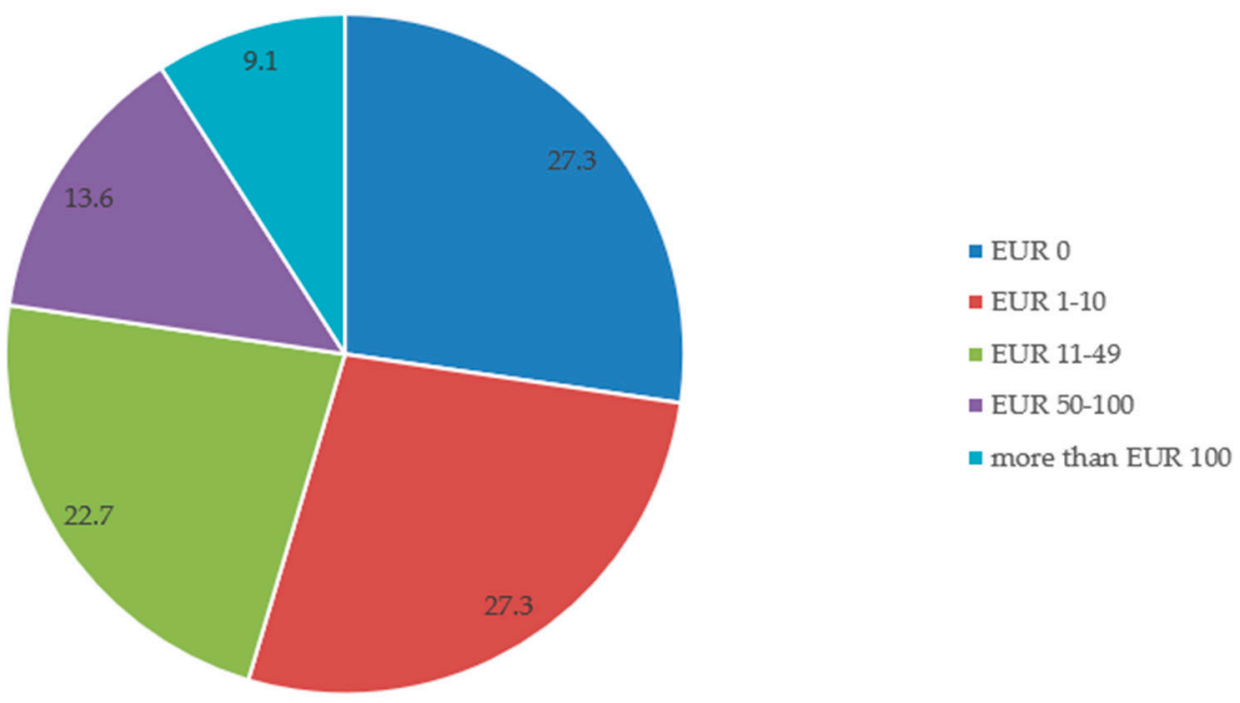

Figure 8. Distribution of the sample according to willingness to pay "one-off" rates.

The situation is different if the management of green areas through a private companyis proposed, through fundraising with a collection of residents of the neighbourhood (crowfounding) called "green tax", with a possible reduction inthe amount paid by municipal taxes. The sample is in favour of this initiative by $87 \%$, with only $13 \%$ unfavourable. This hypothesis also changes the willingness to bear the costs by the respondents who, under these conditions, declare themselves to be much more willing to support, with a distribution by bands different from the first hypothesis (i.e., to pay a one-off). In particular, the answers of the sample are reported in Figure 9, which shows a different predisposition of citizens to pay their contribution, in the face of a refund of the amount paid on municipal taxes. In fact, although the share of those who are not willing to pay is still significant $(17.4 \%)$, only $4.3 \%$ choose the EUR $1-10$ range, while it can be seen that $34.8 \%$ are willing to contribute amounts between EUR 11 and 49,17.4\% for amounts in the EUR 50-100 range, and $26.1 \%$ are willing to pay more than EUR 100.

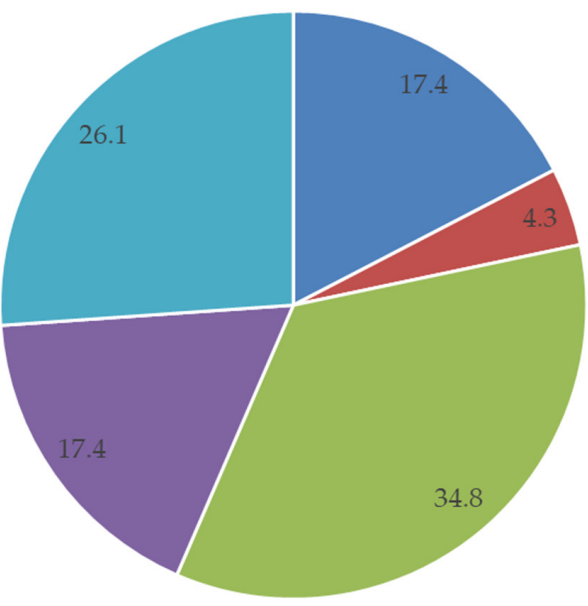

- EUR 0

- EUR 1-10

- EUR 11-49

- EUR 50-100

- more than EUR 100

Figure 9. Distribution of the sample by ranges of willingness to pay with the hypothesis of a reduction in municipal taxes.

The results obtained from the responses of citizens show that there is a positive perception of citizens regarding the importance of green infrastructure in the urban ecosystem, but awareness of the important benefits that it is able to provide in terms of ecosystem services is not yet fully mature. 


\section{Discussion}

The survey carried out in the metropolitan city of Catania has allowed us to acquire important information on the perception of the role of urban green and trees by citizens, both on the quality of life, on one hand, and on climate change, on the other. Citizens perceive the benefits of urban nature, which is able to satisfy important intangible human needs, as already highlighted in other studies $[10,15,28,58,59,61,62]$, even if the full awareness of the benefits of some ecosystem services is not yet mature. Citizens associated urban green spaces with the following benefits: higher air quality, landscape, fruition and recreation. On the other hand, there is still a limited knowledge of the benefits in relation to temperature regulation, $\mathrm{CO}_{2}$ absorption, rainwater regulation and biodiversity conservation.

The preferred GIs still remain parks, which manage to ensure that citizens (especially in traffic-congested cities such as Catania) can satisfy their need to relax, rediscover contact with nature and interrupt the stressful rhythms of daily life. These preferences express the reduced perception of the importance of urban green as a provider of important ecosystem services, some of which are only partly perceived. This is a cultural gap that needs to be filled through targeted actions of information and involvement of local populations on the importance of the presence of natural capital in cities and, in particular, of the various forms of urban green and trees, as also recommended by the FAO [36]. These are actions of co-management of urban green that fall among those planned to support the Sustainable Development Goal (SDG) 11: Creating a more sustainable future for cities and other urban communities [11].

The importance of urban green spaces as a measure of climate adaptation is intuitively perceived by citizens, but there is not yet full awareness and knowledge. The general perception of citizens on climate change is certainly that of an increasingly vulnerable environment (both natural and urban). The effects of climate are increasingly evident in cities, especially extreme events, and the community expresses the need to implement adaptation measures. On the issue of public awareness of the risks of climate change, the IPCC has called for further research and the promotion of public awareness [2]. Adaptation of cities to climate change is one of the major challenges of our time, as climate change affects ecosystem services. Among the beneficial measures to be taken is an increase in green areas, including parks, tree-lined streets, vertical greenery and green roofs, which is also important for mitigating health risks, especially during heat waves.

Ecosystem services provide clear benefits to society and their loss could inevitably lead to serious socio-economic consequences on the one hand and environmental and climate consequences on the other.

Therefore, the integration of the ecosystem services assessment process in urban areas should be considered as a part of the project evaluation procedure and adequately accounted for in policy decisions and urban planning strategies, according to an eco-socialgreen model [20]. In this new green urban planning approach, the participation of citizens is fundamental, as the more they are involved in planning interventions, the more they become co-actors in the realisation of a sustainable and resilient city. Unfortunately, in Italy, especially in the southern regions of the country, participatory planning with the involvement of citizenship for the creation of new urban areas or the redevelopment of degraded or abandoned areas is hardly becoming widespread practice [6,7].

From the results that emerged from the survey, the need to integrate specific urban sustainability indicators based on urban green areas into the planning processes could be highlighted. In particular, they could be based on the presence of GIs, on their degree of public use, on the degree of citizens' satisfaction, on the degree of perception, also in relation to citizens' age(in order to design urban green areas capable of satisfying the needs and expectations of all segments of the population (children, families, elderly, disabled, etc.).

The image of urban green and trees, and in general of natural capital, as a common public good is not yet present in the majority of citizens, but each of us inhabitants of the planet are responsible for its preservation and maintenance for future generations. The citizens' expression of their WTP for urban green highlighted that urban GIs are still 
seen as a public good for which local governments are primarily responsible. Certainly, the monetary valuation is strongly influenced by the socio-economic variables of the population, but it is likely that information interventions and environmental education could favour a greater attention to environmental issues by citizens, as well as an active approach in these issues. Only the incentive for a refund of municipal taxes pushes the respondents to a greater willingness to pay, which should be further tested. In fact, it should be pointed out that the results presented are a first contribution of a research still in progress and what is reported is the manifestation of the willingness to pay of the sample, but a contingent valuation was not carried out here, which will be developed in the next phase of the project.

Therefore, despite this limitation, the important contribution that the research made is to have acquired the primary information on the attitude of the population of Catania about the importance attributed to urban green and its ecosystem services, their relationship with climate change and, finally, the intention to contribute to the co-management of urban green, both in terms of participatory planning and monetary contribution (expressed as willingness to pay).

The results have highlighted some positive effects of green-oriented planning, which may be useful to:

- Implement development plans that promote co-managed urban green spaces;

- Develop design proposals for urban green spaces to control the heat island effect;

- $\quad$ Create and promote green jobs;

- Convert degraded areas, marginal areas and backyards into green spaces;

- $\quad$ Promote community gardens, urban agriculture and urban food forests;

- $\quad$ Increase the number of green buildings.

\section{Conclusions}

Trees have taken on a strategic identity and begun to conquer space in the city thanks to the stimulus of the community, as they did in the industrial revolution of the 19th century. In the modern city, trees evoke the existence of the natural world, to which man has always related at various times and in various ways, and which he now tends to forget. Cities will have to make room for trees not only for economic and social reasons, but also for the need to re-establish a direct relationship with nature and for a simple cost-benefit analysis of environmental hygiene. A decisive contribution can be made by citizens, who now seem to be willing to play an active role in the design and management of urban green spaces, even if this willingness is not equally widespread across the territory.

Many scientific studies and initiatives developed in many cities, andon the basis of incentives from international bodies, have raised awareness that planning tree living spaces contributes to the quality of life in the city in various ways. In particular, the tree and the surrounding ecosystem complex contribute to the following aspects:

- Environmental: air and water purification, $\mathrm{CO}_{2}$ storage, climate and acoustic mitigation, water runoff;

- Ecological: biodiversity, ecological corridors, ecological networks;

- $\quad$ Economic: property value, physiological and psychological well-being, energy, greenways and sustainable mobility;

- $\quad$ Aesthetic: history, form, architectural beauty, education, culture, sociality, sport.

It is clear that poor management of trees in urban areas and a lack of planning and regulation contribute to urban quality in the opposite direction, generating the following negative effects for each aspect:

- Environmental: increase in water and air pollution, noise pollution and soil erosion and runoff phenomena, soil sealing;

- Ecological: impoverishment of biodiversity, disruption of urban microclimate and general climatic conditions; 
- Economic decrease in property value, increase in health, energy and urban mobility costs;

- Aesthetic: unhealthy and dirty cities with conflicts with vandalism problems and social problems in general.

In recent years, there has been a general trend towards greater awareness among citizens of the importance of greenery in the urban ecosystem and the ecosystem services it provides. Very often, it is an intuitive rather than rational awareness, but there is certainly a growing attention.

The research carried out in the city of Catania (Italy) used an integrated assessment model that proved useful to analyse and evaluate citizens' perception of the importance of urban green and trees and the degree of interest in their participation in green-oriented urban planning. The results showed that among the three alternative scenarios proposed, the "TREES" scenario was preferred, which envisages the presence of trees and green spaces in the city, confirming the general demand for the presence of greenery in the urban environment, as other research and initiatives have highlighted, as already mentioned.

A cultural gap has been detected among the citizens of Catania, with regard to the reduced knowledge of the ecosystem services provided by the green system and their importance for the well-being of the community, also in relation to climate change. The results concerning the willingness to pay for a co-management of urban green areas were interesting, showing a favourable response only following incentives in the form of a reduction on paid municipal taxes. This result demonstrates, once again, the lack of awareness among citizens of urban green areas as a public good to be protected and for which they are all responsible in its management. In this sense, municipal institutions are called upon to encourage the dissemination of the importance of green areas and trees in the urban context, on the one hand, and to promote initiatives of participation and collaboration in urban green projects, on the other. To this end, it will be very important to use assessment methodologies to be able to translate citizens' expectations into possible directions in green-oriented, resilient and inclusive planning, and the proposed model has proven to be useful and potentially replicable in other contexts.

"... To have much greener, more resilient and regenerative cities, we need to rethink the way urban and peri-urban areas are designed and managed ..., ... We only have ten years left to achieve the Sustainable Development Goals. We must radically change our perspective and rethink our business models ..." ". These were the words of FAO Director-General QU Dongyu in his opening speech at the virtual event [10]. In Italy, within the PNRR (National Recovery and Resilience Plan, financed by the Recovery Fund), actions are foreseen specifically to orient cities towards green-oriented initiatives. In particular, about EUR 330 million are planned for the protection and enhancement of urban and suburban green areas. The aim is to plant at least 6.6 million trees (for 6600 hectares of urban forests) in fourteen Italian metropolitan cities to improve the quality of life and well-being of citizens through the development of urban and peri-urban forests. The aim is to "preserve and enhance widespread naturalness, biodiversity and ecological processes linked to fully functional ecosystems", contribute to are duction in air pollution in metropolitan areas and reduce air quality infringement procedures.

The numerous plans, programmes and initiatives that are being developed and implemented at a global level, not least the objectives of COP 26 held in Glasgow from 31 October to 12 November 2021, aim to guide governments, at all levels, towards innovative development models in terms of both objectives and planning, participation and assessment tools, as well as in economic, social and environmental terms, capable of involving all stakeholders, especially citizens, who are the main users of the important ecosystem services offered by trees and green spaces. As suggested by the FAO guidelines [35], in the near future, it will be increasingly important to activate strategic, integrated and inclusive forms of governance, capable of activating more participatory city policies for the sharing and co-management of urban green spaces in order to grow and develop "green cities" with a strategic role assigned to trees. 
Author Contributions: Conceptualization, L.S. and A.S.; methodology, A.S.; software, A.S. and G.T.; investigation, G.T.; writing-original draft preparation, L.S. and A.S.; writing-review and editing, L.S.; funding acquisition, A.S. All authors have read and agreed to the published version of the manuscript.

Funding: This study is supported by the research project PIAno di inCEntivi per la RIcerca di Ateneo 2020/2022 (PIACERI) -UNICT LINE 2-2020/2022—“Sostenibilità ed innovazioni della ricerca in agricoltura, alimentazione e ambiente".

Institutional Review Board Statement: Not applicable.

Informed Consent Statement: Not applicable.

Data Availability Statement: Data are available at the Department of Agriculture, Food, and Environment, University of Catania, Italy.

Conflicts of Interest: The authors declare no conflict of interest.

\section{References}

1. FAO. Tree Cities of the World. Bulletin Zero. 2020. Available online: https://treecitiesoftheworld.org/documents/tcow-bulletinzero.pdf (accessed on 23 October 2021).

2. IPCC. Global Warming of $1.5^{\circ} \mathrm{C}$ : An IPCC Special Report on the impacts of Global Warming of $1.5^{\circ} \mathrm{C}$ above Pre-Industrial Levels and Related Global Greenhouse Gas Emission Pathways, in the Context of Strengthening the Global Response to the Threat of Climate Change, Sustainable Development, and Efforts to Eradicate Poverty; Masson-Delmotte, V., Zhai, P., Pörtner, H.-O., Roberts, D., Skea, J., Shukla, P.R., Pirani, A., Moufouma-Okia, W., Péan, C., Pidcock, R., et al., Eds.; In press; Available online: https: //www.ipcc.ch/site/assets/uploads/sites/2/2019/06/SR15_Full_Report_Low_Res.pdf (accessed on 18 May 2021).

3. United Nations (UN). Revision of the World Urbanization Prospects; United Nations: New York, NY, USA, 2018.

4. United Nations (UN). The Sustainable Development Goals Report 2020; United Nations, Department of Economic and Social Affairs: New York, NY, USA, 2020.

5. Fischer, J.; Lindenmayer, D. Landscape modification and habitat fragmentation: A synthesis. Glob. Ecol. Biogeogr. 2007, 16, 265-280. [CrossRef]

6. LEGAMBIENTE. Mal'Aria di Città. 2021. Available online: https://www.legambiente.it/wp-content/uploads/2021/01/ Rapporto_Malaria_2021.pdf (accessed on 10 October 2021).

7. LEGAMBIENTE. Il clima è giàcambiato. Rapporto 2020 CittàClima. 2020. Available online: https: / cittaclima.it/2020/11/10 / presentazione-del-rapporto-2020-dellosservatorio-di-legambiente-cittaclima/ (accessed on 10 October 2021).

8. Ferrini, F.; Romano, D.; Fini, A. La stimadeiparchi, giardini e alberature. In Proceedings of the Atti del ConvegnoEstimo: Scienza del metodo. I Tempidella Terra; 2020; pp. 66-77. Available online: www.itempidellaterra.it (accessed on 10 September 2021).

9. Sturiale, L.; Scuderi, A. The Role of Green Infrastructures in Urban Planning for Climate Change Adaptation. Climate 2019, 7, 119. [CrossRef]

10. FAO. Green Cities to Build Back Better for SDGs-A New Powerful Venture. Virtual Event 18/09/2020. Available online: https:/ / www.fao.org/about/meetings/fao-green-cities-initiative/en/ (accessed on 20 September 2021).

11. UN. Transforming Our World: The 2030 Agenda for Sustainable Development; UN DESA: Department of Economic and Social Affairs: New York, NY, USA, 2015.

12. Forest Research. Benefits of Green Infrastructures; Report by Forest Research; Forest Research: Farnham, UK, 2010.

13. European Commission. The Multifuntionality of Green Infrastructures; Science for Environment Policy/In-depth Reports; European Commission: Brussels, Belgium, 2012.

14. Breuste, J.; Artmann, M.; Li, J.X.; Xie, M.M. Special issue on green infrastructure for urban sustainability. J. Urban Plan. Dev. 2015, 141, A2015001. [CrossRef]

15. Tzoulas, K.; Korpela, K.; Venn, S.; Yli-Pelkonen, V.; Kázmierczak, A.; Niemela, J.; James, P. Promoting ecosystem and human health in urban areas using green infrastructure: A literature review. Landsc. Urban Plan. 2007, 81, 167-178. [CrossRef]

16. Jayasooriya, V.M.; Muthukumaran, A.W.M.N.G.S.; Perera, B.J.C. Green infrastructure practices for improvement of urban air quality. Urban For. Urban Green. 2017, 21, 34-47. [CrossRef]

17. Gill, S.E.; Handley, J.F.; Ennos, A.R.; Pauleit, S. Adapting Cities for Climate Change: The Role of the Green Infrastructure. Built Environ. 2007, 1, 115-133. [CrossRef]

18. Foster, J.; Lowe, A.; Winkelman, S. The Value of Green Infrastructures for Urban Climate Adaptation; Center for Clean Air Policy: Washington, DC, USA, 2011.

19. Escobedo, F.J.; Kroeger, T.; Wagner, J.E. Urban forests and pollution mitigation: Analyzing ecosystem services and disservices. Environ. Pollut. 2011, 159, 2078-2087. [CrossRef]

20. Sturiale, L.; Scuderi, A. The Evaluation of Green Investments in Urban Areas: A Proposal of an eco-social-green Model of the City. Sustainability 2018, 10, 4541. [CrossRef]

21. Bolund, P.; Hunhammar, S. Ecosystem services in urban areas. Ecol. Econ. 1999, 29, 293-301. [CrossRef] 
22. Reid, W.V.; Mooney, H.A.; Cropper, A.; Capistrano, D.; Carpenter, S.R.; Chopra, K.; Kasperson, R. Ecosystems and Human Well-Being-Synthesis: A Report of the Millennium Ecosystem Assessment; Island Press: Washington, DC, USA, 2005.

23. Santolini, R. Ecosystem services and urban areas. In Urban Landscapes. Environmental Network and Quality of Life; Sargolini, M., Ed.; Springer: Berlin/Heidelberg, Germany, 2012.

24. Elmqvist, T.; Setälä, H.; Handel, S.; van der Ploeg, S.; Aronson, J.; Blignaut, J.N.; Gómez-Baggethun, E.; Nowak, D.J.; Kronenberg, J.; de Groot, R. Benefits of restoring ecosystem services in urban areas. Curr. Opin. Environ. Sustain. 2015, 14, 101-108. [CrossRef]

25. European Environmental Agency (EEA). Air Quality in Europe. 2018. Available online: https://www.eea.europa.eu/ /publications / air-quality-in-europe-2018 (accessed on 15 November 2021).

26. MINAMB. Le Infrastrutture Verdi e iServiziEcosistemici in Italia Come Strumento per le PoliticheAmbientali e la Green Economy: Potenzialità, Criticità e Proposte; Ministerodell'Ambiente: Roma, Italy, 2013.

27. Manes, F.; Silli, V.; Salvatori, E.; Incerti, G.; Galante, G.; Fusaro, L.; Perrino, C. Urban ecosystem services: Tree diversity and stability of PM10 removal in the metropolitan area of Rome. Ann. Bot. 2014, 4, 19-26.

28. Shanahan, D.F.; Bush, R.; Gaston, K.J.; Lin, B.B.; Dean, J.; Barber, E.; Fuller, R.A. Health benefits from nature experiences depend on dose. Sci. Rep. 2016, 6, 28551. [CrossRef] [PubMed]

29. Millennium Ecosystem Assessment (MEA). Ecosystems and Human Well-Being: Biodiversity Synthesis; World Resources Institute: Washington, DC, USA, 2005.

30. Haines-Young, R.H.; Potschin, M.B. Common International Classification of Ecosystem Services (CICES) v.5.1 and Guidance on the Application of the Revised Structure; Fabis Consulting Ltd.: Nottingham, UK, 2018. Available online: https:// cices.eu (accessed on 28 September 2021).

31. Orsini, F.; Kahane, R.; Nono-Womdim, R.; Gianquinto, G. Urban agriculture in the developing world: A review. Agron. Sustain. Dev. 2013, 33, 695-720. [CrossRef]

32. Foti, V.T.; Scuderi, A.; Stella, G.; Sturiale, L.; Timpanaro, G.; Trovato, M.R. The integration of agriculture in the politics of social regeneration of degraded urban areas. In Integrated Evaluation for the Management of Contemporary Cities. Results of SIEV, Green Energy and Technology; Mondini, G., Fattinnanzi, E., Oppio, A., Bottero, M., Stanghellini, S., Eds.; Springer: Cham, Switzerland, 2016; pp. 99-111.

33. Scuderi, A.; Sturiale, L.; Bellia, C.; Foti, V.T.; Timpanaro, G. The redefinition of the role of agricultural areas in the city of Catania. Riv. Di Studi Sulla Sostenibilità 2016, 2, 237-247. [CrossRef]

34. Fetouh, M.I. Edible landscaping in urban horticulture. Urban Hortic. 2018, 18, 141-173.

35. FAO. Guidelines on Urban and Peri-Urban Forestry; Salbitano, F., Borelli, S., Conigliaro, M., Chen, Y., Eds.; FAO Forestry Paper No.178; Food and Agriculture Organization of the United Nations: Rome, Italy, 2016.

36. FAO; ITPS; GSBI; CBD; EC. State of Knowledge of Soil Biodiversity-Status, Challenges and Potentialities, Report 2020; FAO: Rome, Italy, 2020.

37. Park, H.; Kramer, M.; Rhemtulla, J.M.; Konijnendijk, C.C. Urban food systems that involve trees in Northern America and Europe: A scoping review. Urban For. Urban Green. 2019, 45, 126360. [CrossRef]

38. Luley, C.J.; Bond, J. A Plan to Integrate Management of Urban Trees into Air Quality Planning; Report Prepared for NY Department of Environmental Conservation and USDA Forest Service; Northeastern Research Station: Burlington, MA, USA, 2002.

39. Paoletti, E.; Bardelli, T.; Giovannini, G.; Pecchioli, L. Air quality impact of an urban park over time. Procedia Environ. Sci. 2011, 4, 10-16. [CrossRef]

40. McPherson, E.G.; Nowak, D.; Heisler, G.; Grimmond, S.; Souch, C.; Grant, R.; Rowntree, R. Quantifying urban forest structure, function, and value: The Chicago Urban Forest Climate Project. Urban 1997, 1, 49-61.

41. Tallis, M.; Taylor, G.; Sinnett, D.; Freer-Smith, P. Estimating the removal of atmospheric particulate pollution by the urban tree canopy of London, under current and future environments. Landsc. Urban Plan. 2011, 103, 129-138. [CrossRef]

42. Rogers, K.; Sacre, K.; Goodenough, J.; Doick, K. Valuing London's urban forest: Results of the London i-Tree eco project Treeconomics London. 2015. Available online: www.itreetools.org/resources/reports/Valuing_Londons_Urban_Forest.pdf (accessed on 24 October 2021).

43. Nowak, D.J.; Crane, D.E.; Stevens, J.C. Air pollution removal by urban trees and shrubs in the United States. Urban For. Urban Green. 2006, 4, 5-123. [CrossRef]

44. Georgi, N.J.; Zafiriadis, K. The impact of park trees on microclimate in urban areas. Urban Ecosyst. 2006, 9, 195-209. [CrossRef]

45. Baris, M.E.; Satris, S.; Yargon, M.E. The contribution of trees and green spaces to the urban climate: The case of Ankara. Afr. J. Agric. Res. 2009, 4, 791-800.

46. Nowak, D.J. The Effects of Urban Trees on Air Quality; USDA Forest Service: Washington, DC, USA, 2002.

47. Gibelli, G.; Fontana Sartorio, M.; Lodi, M.; Santolini, R. Landscapes functions and human health: Incidence of environmentalchanges. J. Mediterr. Ecol. 2007, 8, 27-42.

48. Costanza, R.; d'Arge, R.; De Groot, R.; Farber, S.; Grasso, M.; Hannon, B.; Limburg, K.; Naeem, S.; O’Neill, R.V.; Paruelo, J.; et al. The value of the world's ecosystem services and natural capital. Nature 1997, 387, 253-260. [CrossRef]

49. Toman, M. Why not to calculate the value of the world's ecosystem services and natural capital. Ecol. Econ. 1998, 25, 57-60. [CrossRef]

50. European Union (EU). Adapting to Climate Change: Towards a EUROPEAN Framework for Action; White Paper; COM 2009 147/4; EU: Brussels, Belgium, 2009. 
51. Environment Directorate-General for the Environment. Communication from the commission to the European Parliament, the Council, the European Economic and Social Committee and the Committee of the Regions. Green Infrastructure (GI)_Enhancing Europe's Natural Capital; Environment Directorate-General for the Environment: Brussels, Belgium, 2013.

52. European Commission. The Forms and the Functions of the Green Infrastructures; European Commission: Brussels, Belgium, 2016.

53. EEA. Green Infrastructure and Territorial Cohesion. The Concept of Green Infrastructure and Its Integration into Policies Using Monitoring Systems; Technical Report No. 18/2011; European Environment Agency: Copenhagen, Denmark, 2011.

54. Munafò, M. (a cura di). Consumo di suolo, Dinamicheterritoriali e Serviziecosistemici; Report SNPA 22/21/2021; Edizione: Treviso, Italy, 2021.

55. The Nature Conservancy. Planting Healthy Air. A Global Analysis of the Role of Urban Trees in Addressing Particulate Matter Pollution and Extreme Heatlth. 2016. Available online: https://www.nature.org/content/dam/tnc/nature/en/documents/2016 0825_PHA_ExSummary_Final.pdf (accessed on 27 October 2021).

56. Dwyer, J.-F.; McPherson, E.-G.; Schroeder, H.-W.; Rowntree, R.A. Assessing the benefits and costs of the urban forest. J. Arboric. 1992, 18, 227-234.

57. City of Seattle. Urban Forest Strategic Plan-Phone Survey of Seattle Residents; Cascadia Consulting Group: Seattle, OR, USA, 2000.

58. Lohr, V.I.; Pearson-Mims, C.H.; Tarnai, J.; Dillman, D.A. How urban residents rate and rank the benefits and problems associated with trees in cities. J. Arboric. 2004, 30, 28-35. [CrossRef]

59. Sommer, R.; Learey, F.; Summit, J.; Tirrel, M. The social benefits of resident involvement in tree planting. J. Arboric. 1994, 20, 170-175.

60. Wolf, K.L. Trees and business district preferences: A case study of Athens, Georgia. USJ. Arboric. 2004, 30, 336-346. [CrossRef]

61. Qin, J.; Zhou, X.; Sun, C.; Leng, H.; Lian, Z. Influence of green spaces on environmental satisfaction and physiological status of urban residents. Urban For. Urban Green. 2013, 12, 490-497. [CrossRef]

62. Camacho-Cervantes, M.; Schondube, J.E.; Castillo, A.; Macgregor-Fors, I. How do people perceive urban trees? Assessing likes and dislikes in relation to the trees of a city. Urban Ecosyst. 2014, 17, 761-773. [CrossRef]

63. Sanesi, G.; Chiarello, F. Residents and urban green spaces: The case of Bari. Urban For. Urban Green. 2006, 4, 125-134. [CrossRef]

64. Sturiale, L.; Scuderi, A.; Timpanaro, G.; Foti, V.T.; Stella, G. Social and inclusive "value" generation in metropolitan area with the "urban gardens" planning. Green Energy Technol. 2020, 285-302. [CrossRef]

65. Economides, C. Green Infrastructure: Sustainable Solutions in 11 Cities across the United States; Columbia University Water: New York, NY, USA, 2014

66. Caspersen, O.H.; Olafsson, A.S. Recreational mapping and planning for enlargement of the green structure in greater Copenhagen. Urban For. Urban Green. 2010, 9, 101-112. [CrossRef]

67. Ka-bisch, N. Ecosystem service implementation and governance challenges in "urban green spaces" planning-the case of Berlin, Germany. Land Use Policy 2015, 42, 557-567. [CrossRef]

68. Jim, C.Y. PlanningstrategiestoovercomeconstraintsongreenspaceprovisioninurbanHongKongTown. Plan. Rev. 2002, 73, 127-152.

69. Yang, J.; Mcbride, J.; Zhou, J.; Sun, Z. The urban forest in Beijing and its role in air pollution reduction. Urban For. Urban Green. 2005, 3, 65-78. [CrossRef]

70. Wei, J.; Qian, J.; Tao, Y.; Hu, F.; Ou, W. Evaluating Spatial Priority of Urban Green Infrastructure for Urban Sustainability in Areas of Rapid Urbanization: A Case Study of Pukouin China. Sustainability 2018, 10, 327. [CrossRef]

71. Scuderi, A.; Sturiale, L.; Timpanaro, G.; La Via, G.; Pecorino, B. A Possible Circular Approach for Social Perception of Climate Adaptation Action Planning in Metropolitan Cities. Green Energy Technol. 2021, 155-169. [CrossRef]

72. Munda, G. Social Multicriteria Evaluation for a Sustainable Economy; Springer: Berlin/Heidelberg, Germany, 2008.

73. Munda, G. ANAIADE based Approach for Sustainability Benchmarking. Int. J. Environ. Technol. Manag. 2006, 6, 65-78. [CrossRef]

74. Lorenzo, A.B.; Blanche, C.A.; Qi, Y.; Guidry, M.M. Assessing residents' willingness to pay to preserve the community urban forest: A small-city case study. J. Arboric. 2000, 26, 319-325.

75. Deli, I. A TOPSIS method by using generalized trapezoidal hesitant fuzzy numbers and applicationto a robot selection problem. J. Intell. Fuzzy Syst. 2020, 38, 779-793. [CrossRef]

76. Deli, I.; Karaaslan, F. Generalized trapezoidal hesitant fuzzy numbers and their applications to multicriteria decision-making problems. Soft Comput. 2021, 25, 1017-1032. [CrossRef]

77. Deli, I.; Ali Keleş, M. Distance Measures on Trapezoidal Fuzzy Multi-Numbers and Application to Multi-Criteria Decision-Making Problems. Soft Comput. 2021, 25, 5979-5992. [CrossRef]

78. Likert, R. A technique for measurement of attitudes. Arch. Psychol. 1932, 140, 5-55. 